\title{
SATISFACTION AND LOYALTY OF LITHUANIAN RURAL TOURISTS: SEGMENTATION AND MANAGERIAL IMPLICATIONS
}

\author{
Viktorija GrigaliūNaité丶1 ${ }^{1}$ Lina PilelienĖ ${ }^{2}$ \\ Vytautas Magnus University (Lithuania)
}

\begin{abstract}
Tourism is becoming a very important and fast growing industry, where rural tourism is a very important part. Tourist loyalty is a very important factor determining tourist's wish to revisit the destination; and main loyalty's antecedent is tourist satisfaction. Accordingly, the research was provided endeavouring to determine how to turn satisfied Lithuanian rural tourists into loyal ones. The aim of the research was to reveal core factors affecting Lithuanian rural tourist loyalty. The obtained results reveal that variables that have to be considered to turn already satisfied tourists into loyal are: 'natural features', 'destination marketing' and 'environmental preservation'. Considering that the variable 'natural features' remains at the constant level due to the requirement of large investments, 'environmental preservation' and 'destination marketing' are variables necessitating specific level of compatibility. KEY WORDS: Lithuanian tourism, Rural tourism, Tourist satisfaction, Tourist loyalty.
\end{abstract}

JEL CODES: M310, M390.

DOI: http://dx.doi.org/10.15181/rfds.v14i3.864

Introduction

In Lithuania as well as in many other fast developing countries, tourism is becoming a very important and fast growing industry. However, for Lithuanian tourists two core possibilities exist: 1) going abroad to other countries, and 2) visiting Lithuanian countryside as rural tourists. Considering rural tourism, it has many advantages. Rural tourism can be named as a valuable tool for the sustainable development of rural areas (Peña et al., 2012; Phillips et al., 2013), it can encourage an increase in cultural exchange between urban and rural areas (Randelli et al., 2014), and serves as a basis for sustainable and renewable energy promotion (Baležentis et al., 2012); it makes a significant contribution to the rural economy and to the wider tourism industry (Haven-Tang, Jones, 2012). Furthermore, growing tourism industry is seen as a potential solution to issue such as low employment rates (Rid et al., 2014). Hence, scientific research in the field of rural tourism development is extremely important and necessary.

According to D. Jurdana and D. Frleta (2012), there is increased competition for tourists; therefore, in order to be successful, a thorough analysis of tourist motivation, as well as of tourist satisfaction and

1 Viktorija Grigaliūnaite - specialist (researcher), Master student at Department of Marketing, Faculty of Economics and Management, Vytautas Magnus University. Scientific research areas: customer satisfaction, mathematical methods in marketing

E-mail: v.grigaliunaite@gmail.com

Tel.: +370 37327856

2 Lina Pilelienė - doctor of Social Sciences, Associated Professor at the Department of Marketing, Faculty of Economics and Management, Vytautas Magnus University. Scientific research areas: consumer behaviour, place marketing

E-mail: 1.pileliene@evf.vdu.lt

Tel.: +37037327856 
loyalty is very important. So far, there is strong empirical evidence to suggest that customer satisfaction is an antecedent of customer loyalty, and that there is a positive link between these two constructs. It is well established in tourism literature that both: tourist's satisfaction and tourist's loyalty are partially determined by the assessment of the destination's different attributes (Alegre, Garau, 2010). Therefore, the problem solved in the article is: what are the factors affecting Lithuanian rural tourist loyalty? and how to transform satisfied tourists into loyal ones?

The object of the research is: factors affecting Lithuanian rural tourist loyalty.

The aim of the research is to reveal core factors affecting Lithuanian rural tourist loyalty.

To meet the aim of the article following tasks were set:

- To establish a prototype of Lithuanian rural tourist.

- To identify essential variables for converting satisfied Lithuanian rural tourist into the loyal one.

- To design the algorithm for turning satisfied Lithuanian rural tourist into loyal.

Research methods. Achieving to reach the aim of the article, theoretical analysis and synthesis are provided. Tourists' attitudes and evaluations towards rural tourism destinations in Lithuania are determined providing the questionnaire research. Structural equation modelling (SEM) using partial least squares (PLS) path modelling methodology, PLS regression and Classification Tree are applied for statistical analysis. Cluster analysis is provided to establish a prototype of Lithuanian rural tourist and a structure of Lithuanian rural tourism market. Scientific visualization is provided for multivariate data analysis.

\section{Scientific substantiation}

Rural tourism is seen as a valuable and growing sector of the overall tourism market, representing a significant source of income to rural economies (Lo et al., 2011; Marcu et al., 2013; Ghanian et al., 2014). Hence, developing rural tourism becomes very important managerial, as well as scientific issue. According to I. Pop and M. Ghereş (2013), satisfaction among tourists has always been one of the goals for those involved in the tourism industry. Moreover, tourists who experience greater satisfaction are likely exhibit greater loyalty to the destination (Sun et al., 2013). According to M. Lo et al. (2011), a major challenge for rural destination is to understand the perceptions of their customers and what do they expect from the tourism industry.

Tourists in rural areas have the main characteristics of any other tourists; moreover, the consumer of rural tourism must be regarded just like any other consumer, but this concept also derives researcher's attention to some new dimensions that have to be taken into consideration (Pop, Ghereş, 2013). Considering this, our previous researches enabled the elaboration of theoretical Lithuanian Tourist Satisfaction Index model (Pileliené, Grigaliūnaite, 2014) and the verification of Lithuanian Rural Tourist Satisfaction Index (LRTSI) model (see Grigaliūnaite, Pilelienè, 2014). As the determinants of Lithuanian rural tourist satisfaction following factors were identified: 'accommodation and catering', 'destination aesthetics', 'environmental preservation', 'destination marketing' and 'perceived value'; moreover, perceived value is determined by 'natural features', 'destination aesthetics' and 'destination marketing'; 'destination marketing' is determined by 'accommodation and catering', 'activities in destination' and 'environmental preservation'.

F. I. Khalil et al. (2012) highlight that relationship between environmental preservation and rural tourism has a special significance. A. B. Radaca et al. (2012) and B. A. Radac et al. (2013) claim that communication and promotion, achieved through destination marketing, are the key of a successful rural tourism business and attracting new clients. I. Pop and M. Ghereş (2013) and A. Peña et al. (2013) argue that a satisfied tourist is likely to return to that particular place and, even more, to recommend it to others - tourist loyalty will be achieved. Satisfaction is a crucial factor to generate destination loyalty; however, a few studies assert that 
satisfied tourists may not return to the same destination (Shirazi, Mat Som, 2013). This indicates that the relations between determinants of satisfaction, satisfaction, and loyalty in tourist industry need to be studied more.

\section{Research methodology}

The research is based on the previously elaborated theoretical Lithuanian Tourist Satisfaction Index (LTSI) model (see Pilelienè, Grigaliūnaite, 2014) and Lithuanian Rural Tourist Satisfaction Index (LRTSI) model (see Grigaliūnaite, Pileliené, 2014). Accordingly, the model used for this research could be represented with structural equations $(1-4)$ :

(1) Destination marketing $=\beta 60+\beta 61$ Accommodation and catering $+\beta 62$ Activities in destination $+\beta 65$ Environmental preservation $+\zeta 6$;

(2) Perceived value $=\beta 70+\beta 73$ Natural features $+\beta 74$ Destination aesthetics + $\beta 76$ Destination marketing $+\zeta 7$;

(3) Satisfaction $=\beta 80+\beta 81$ Accommodation and catering $+\beta 84$ Destination aesthetics + $\beta 85$ Environmental preservation $+\beta 86$ Destination marketing $+\beta 87$ Perceived value $+\zeta 8 ;$

(4) Loyalty $=\beta 90+\beta 97$ Perceived value $+\beta 98$ Satisfaction $+\zeta 9$.

The results for the analysis are correspondingly obtained from the same respondents' evaluations of the questionnaire for the elaboration of the LRTSI model. The survey was conducted in January and February, 2014; 10-point evaluation scale was applied for the questionnaire; sample size was 200 respondents.

Structural equation modelling (SEM) using partial least squares (PLS) path modelling methodology was applied for determination of core variables and their impact on rural tourist satisfaction, as well as on loyalty. Cluster analysis was provided to establish a prototype of Lithuanian rural tourist and a structure of rural tourism market in Lithuanian. PLS regression was provided to specify the relation among dependent variable and set of predictor variables and Classification Tree was provided to predict membership of cases in clusters, as well as to identify measures for converting satisfied Lithuanian rural tourist into the loyal one. Scientific visualization was provided for multivariate data analysis.

\section{Analysis of the research results}

Based on the hierarchical cluster analysis regarding dendrogram and scree plot, the indicated number of segments was three. K-means Clustering analysis revealed that the first cluster contains 26 cases, the second cluster holds 93 cases, and the third cluster covers 81 cases. The Euclidean distances between the final clusters centres are great (see Table 1), corresponding to great dissimilarities between clusters.

Table 1. Distances between Final Cluster Centres

\begin{tabular}{|l|l|l|l|}
\hline \multicolumn{1}{|c|}{ Cluster } & \multicolumn{1}{|c|}{$\mathbf{1}$} & \multicolumn{1}{c|}{$\mathbf{2}$} & \multicolumn{1}{c|}{$\mathbf{3}$} \\
\hline 1 & & 7.733 & 13.348 \\
\hline 2 & 7.733 & & 5.824 \\
\hline 3 & 13.348 & 5.824 & \\
\hline
\end{tabular}

Variables, which contribute the most to the specified cluster solution, are 'satisfaction', 'loyalty', 'environmental preservation', and 'destination marketing' (see Table 2). On the other hand, variables 'destination aesthetics' and 'accommodation and catering' are least valuable in forming and differentiating clusters based on the lowest F-ratio and highest Mean Square error. 
Table 2. ANOVA results

\begin{tabular}{|l|l|l|l|l|l|l|}
\hline \multirow{2}{*}{ Variables } & \multicolumn{2}{c|}{ Cluster } & \multicolumn{2}{c|}{ Error } & \multirow{2}{*}{ F } & \multirow{2}{*}{ Sig. } \\
\cline { 2 - 7 } & \multicolumn{1}{|c|}{ Mean Square } & $\boldsymbol{d f}$ & Mean Square & $\boldsymbol{d f}$ & & \\
\hline Accommodation Catering & 163.232 & 2 & 2.657 & 197 & 61.433 & .000 \\
Activities in destination & 174.165 & 2 & 2.882 & 197 & 60.430 & .000 \\
Natural Features & 202.290 & 2 & 1.831 & 197 & 110.480 & .000 \\
Environmental Preservation & 202.818 & 2 & 1.254 & 197 & 161.697 & .000 \\
Destination Marketing & 202.841 & 2 & 1.427 & 197 & 142.151 & .000 \\
Satisfaction & 267.979 & 2 & 1.005 & 197 & 266.535 & .000 \\
Loyalty & 332.604 & 2 & 1.360 & 197 & 244.593 & .000 \\
Perceived Value & 239.423 & 2 & 1.759 & 197 & 136.118 & .000 \\
Destination Aesthetics & 152.919 & 2 & 4.090 & 197 & 37.384 & .000 \\
\hline
\end{tabular}

Regarding the final cluster centres, the first cluster is assessed as 'frustrated' due to the low evaluations of manifest variables corresponding to the specific latent variables, while the second cluster is assessed as 'satisfied', and the third cluster is assessed as 'loyal' to the particular rural destination due to the average, high and very high evaluations. According to the determined tourist valuations towards the rural destination the core clusters of tourists' behaviour are formed. Consequently, index values of latent variables by the specified clusters (see Table 3) substantiate the designation of the clusters.

Table 3. Index values of latent variables by clusters

\begin{tabular}{|l|l|l|l|}
\hline \multicolumn{1}{|c|}{ Variables } & Frustrated & \multicolumn{1}{c|}{ Satisfied } & Loyal \\
\hline Accommodation and Catering & 42 & 70 & 85 \\
\hline Activities in destination & 43 & 64 & 83 \\
\hline Destination Aesthetics & 32 & 62 & 72 \\
\hline Destination marketing & 51 & 73 & 93 \\
\hline Environmental preservation & 52 & 71 & 94 \\
\hline Loyalty & 37 & 73 & 94 \\
\hline Natural features & 54 & 71 & 95 \\
\hline Perceived Value & 41 & 71 & 89 \\
\hline Satisfaction & 42 & 70 & 92 \\
\hline
\end{tabular}

The R square values of variables 'satisfaction' and 'loyalty' are respectively 80 percent and 79 percent (see Figure 1), thus these values are substantial, and the regression lines approximate the real data points well enough.

SATISFACTION

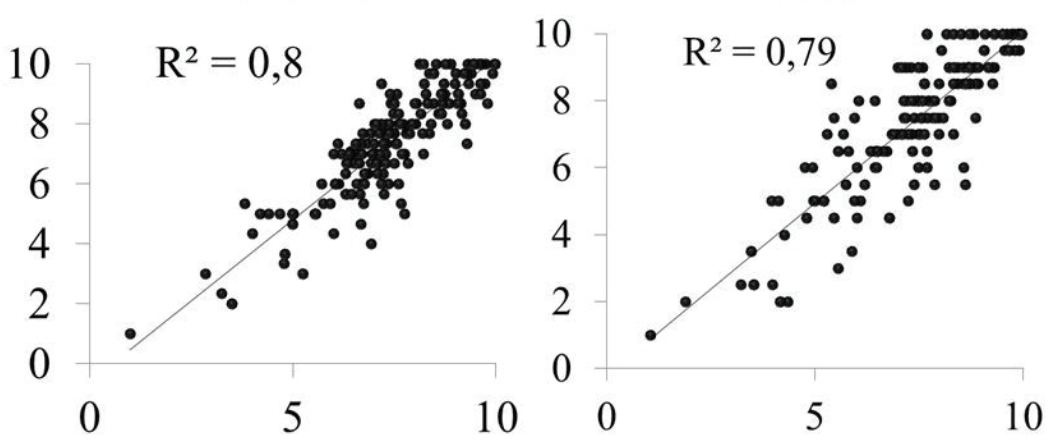

Figure 1. $\mathrm{R}^{2}$ values of variables 'satisfaction' and 'loyalty' 
The values of Variables Importance on partial least squares Projections (VIP) show that not all of the predictors' contributions to fit the model are sufficient (see Figure 2). Variable's 'satisfaction' explanatory variables that contribute the most to fit the model are 'perceived value', 'destination marketing', and 'environmental preservation', while variable's 'destination aesthetics' contribution to fit the model is too small. Consequently, variable 'destination aesthetics' is eliminated from the further analysis. On the other hand, both variable's 'loyalty' explanatory variables have the value of VIP above 0.95 , thus are considered as important.

VIPs (95\% conf. Interval) varlable 'Satisfaction'

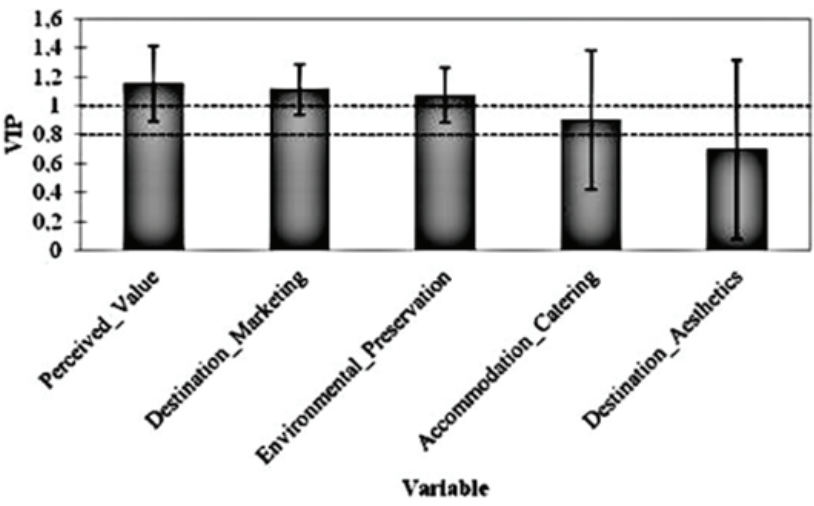

VIPs ( $95 \%$ conf. interval) variable 'Loyalty'

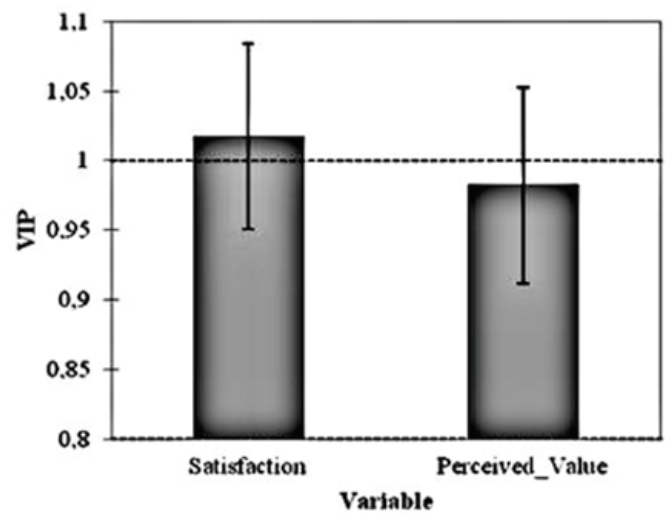

Figure 2. Variables Importance on Partial Least Squares projections

As it can be seen from the dissemination of the clusters (see Figure 3), the 'loyal' cluster is included in the cluster of satisfied tourists; and hence, only satisfied tourist could become loyal. Contrarily, low level of satisfaction indicates that tourist is frustrated with the destination; thus, return on the investments of turning such tourist into the loyal one would be highly questionable.

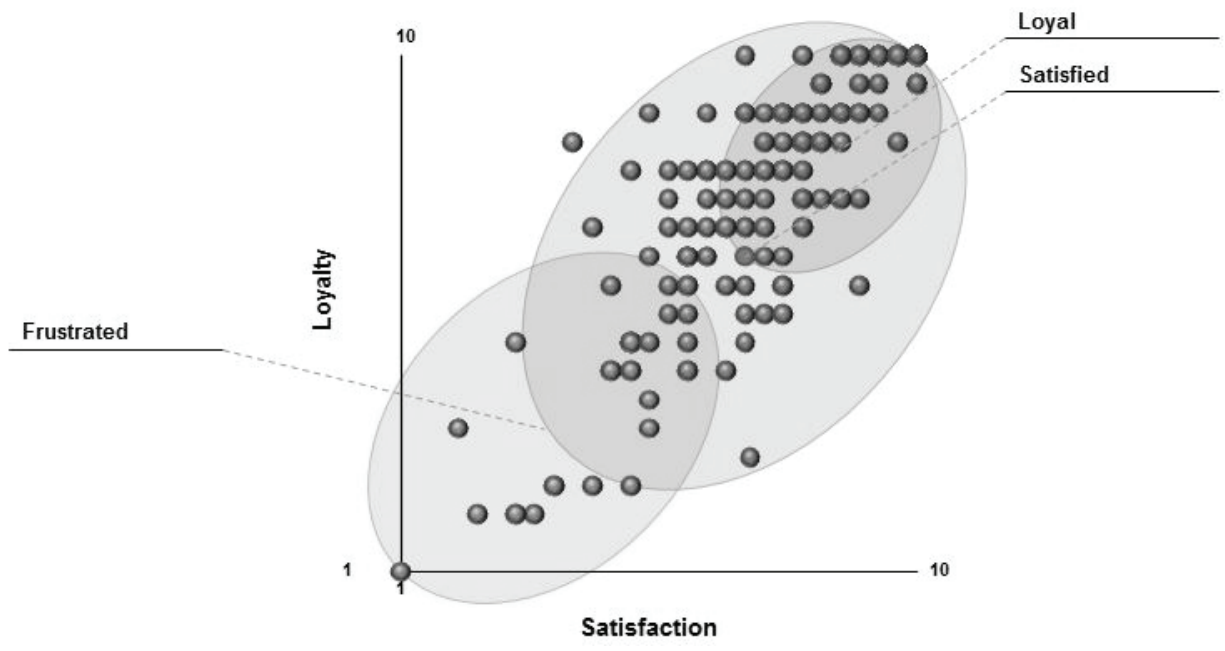

Figure 3. Dissemination of clusters

Perceived Value, Satisfaction, and Loyalty evaluations' model is provided in Figure 4. As tourist satisfaction is the most important determinant of tourist loyalty; it is required that satisfaction must exceed at least average level in order to turn satisfied tourist into the loyal one. On the other hand, analysis of the research results revealed that there is an interaction effect between variables 'satisfaction' and 'perceived value'. Consequently, this effect needs further investigation out of the topic of current research. Accordingly, recommendations regarding the variable 'perceived value' could not be provided and latter variable is eliminated from the further analysis. 

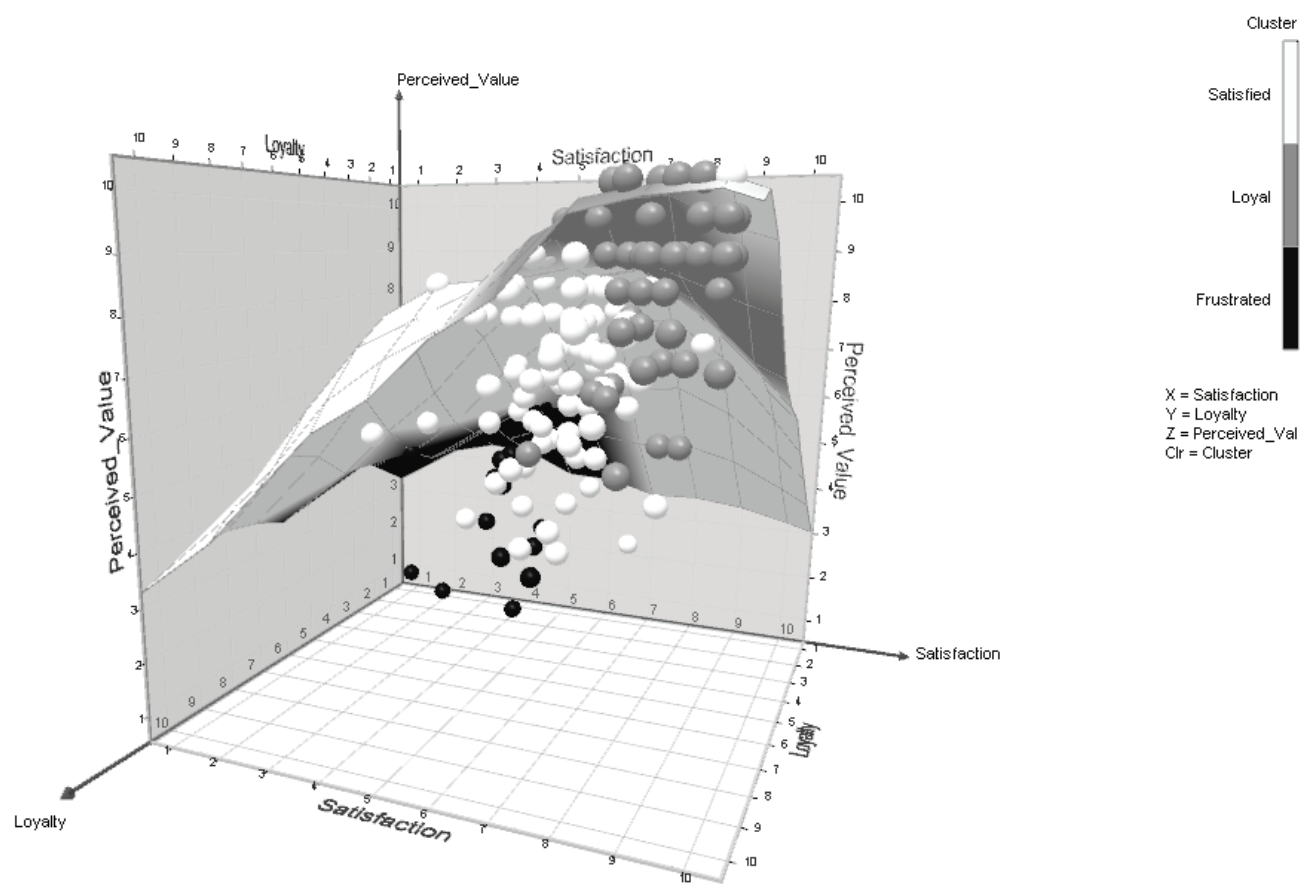

Figure 4. Perceived Value, Satisfaction, and Loyalty evaluations' model

Accommodation and Catering, Satisfaction, and Loyalty as well as Activities in Destination, Satisfaction and Loyalty evaluations' models are provided in Figure 5. VIP values revealed that variable 'accommodation and catering' had the second least contribution to fit the model, furthermore Accommodation and Catering, Satisfaction, and Loyalty evaluations' model supports the assumption that tourist might be loyal to the rural destination despite the low level of accommodation and catering. Moreover, with the highest evaluations of accommodation and catering, there are both satisfied as well as loyal tourists. Consequently, it could be stated that variable 'accommodation and catering' is not the essential variable which could help distinguishing satisfied tourist from the loyal ones.

Variable 'activities in destination' does not directly influence satisfaction as well as loyalty. The only one variable which is directly affected by variable 'activities in destination' is variable 'destination marketing' Additionally, Activities in Destination, Satisfaction, and Loyalty evaluations' model reveals that with the low level of activities in destination or with the very high level of activities in destination, there are many loyal as well as satisfied tourists. Consequently, latter variable does not distinguish satisfied tourist from the loyal ones and this creates no need to invest in this variable when seeking to turn satisfied Lithuanian rural tourist into the loyal.
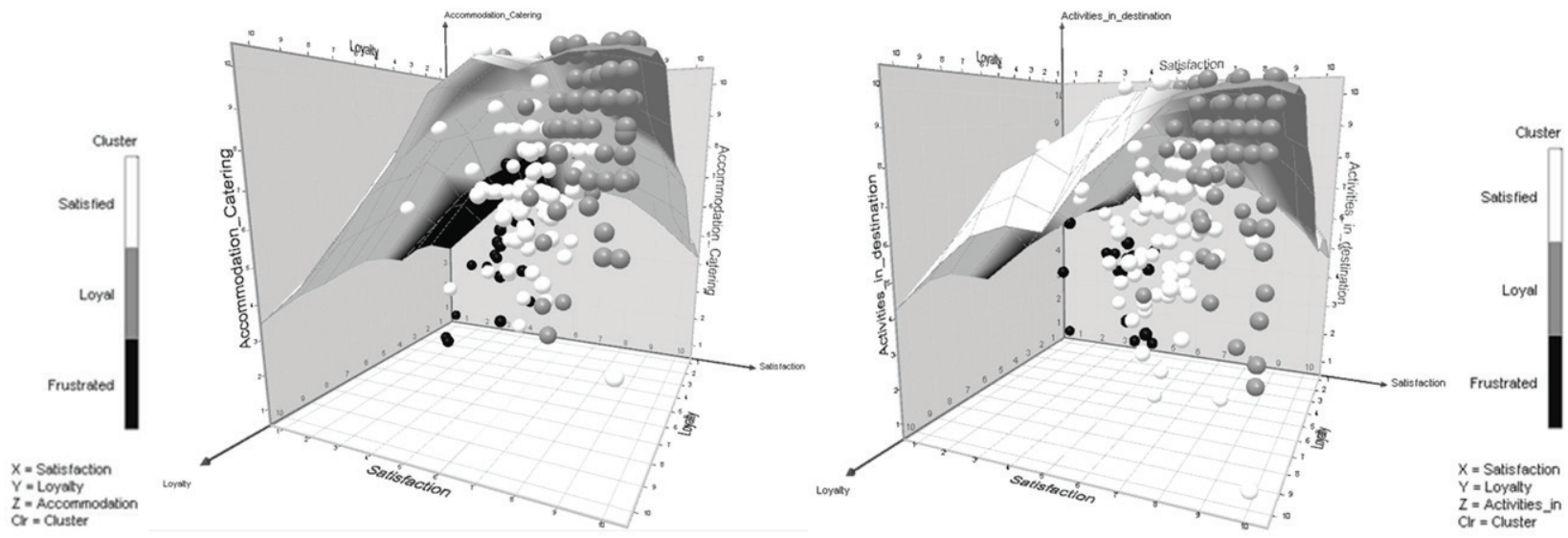

Figure 5. Accommodation and Catering, Satisfaction, and Loyalty and Activities in Destination, Satisfaction, and Loyalty evaluations' models 
Environmental Preservation, Satisfaction, and Loyalty evaluations' model together with Destination Marketing, Satisfaction, and Loyalty evaluations' model are provided in Figure 6. With the highest evaluations of variable 'environmental preservation' as well as with variable 'destination marketing' there are only loyal clusters dispersed. Moreover, there are no loyal tourists when the evaluations of environmental preservation or destination marketing are below average level. Consequently, loyal tourists evaluate variables 'environmental preservation' and 'destination marketing' better than satisfied tourists do. Despite this, there are satisfied tourists even when the level of natural features is evaluated as high. This leads to the assumption that latter variables help distinguishing satisfied tourists from the loyal ones, but the specific combination of these variables must be found which could enable to turn satisfied Lithuanian rural tourist into the loyal one with the lowest costs.
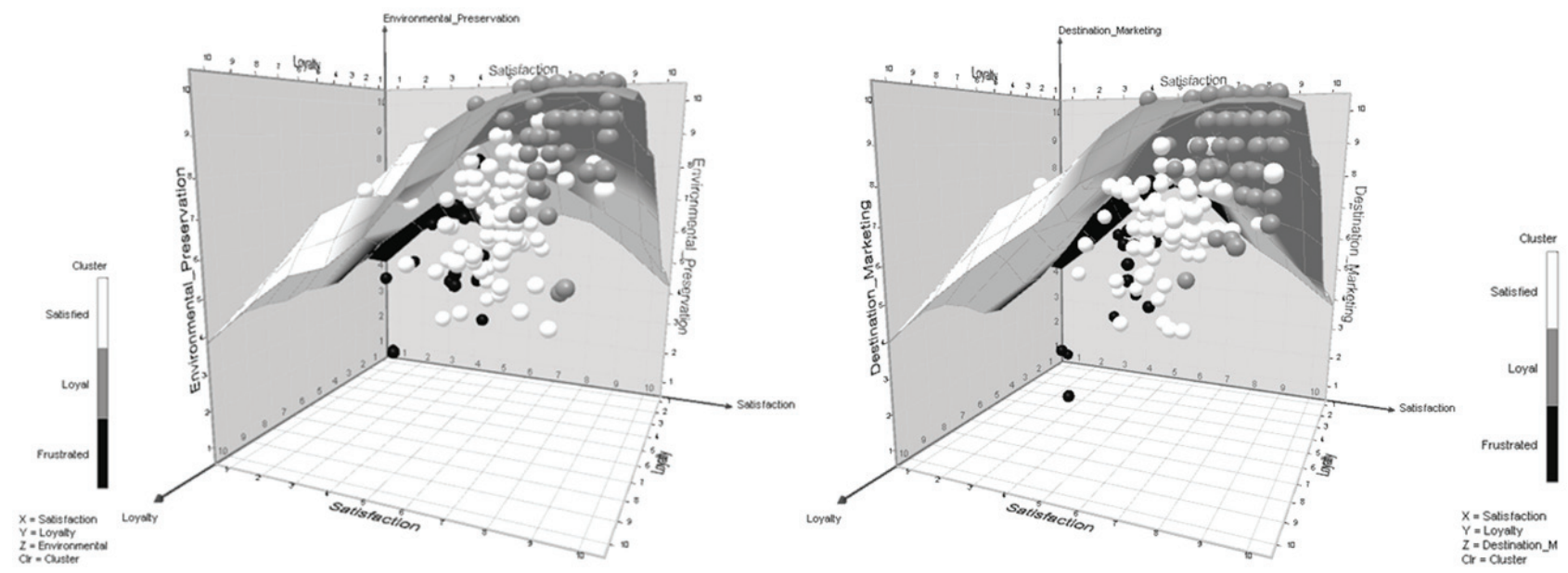

Figure 6. Environmental Preservation, Satisfaction, and Loyalty and Destination Marketing, Satisfaction, and Loyalty evaluations' models
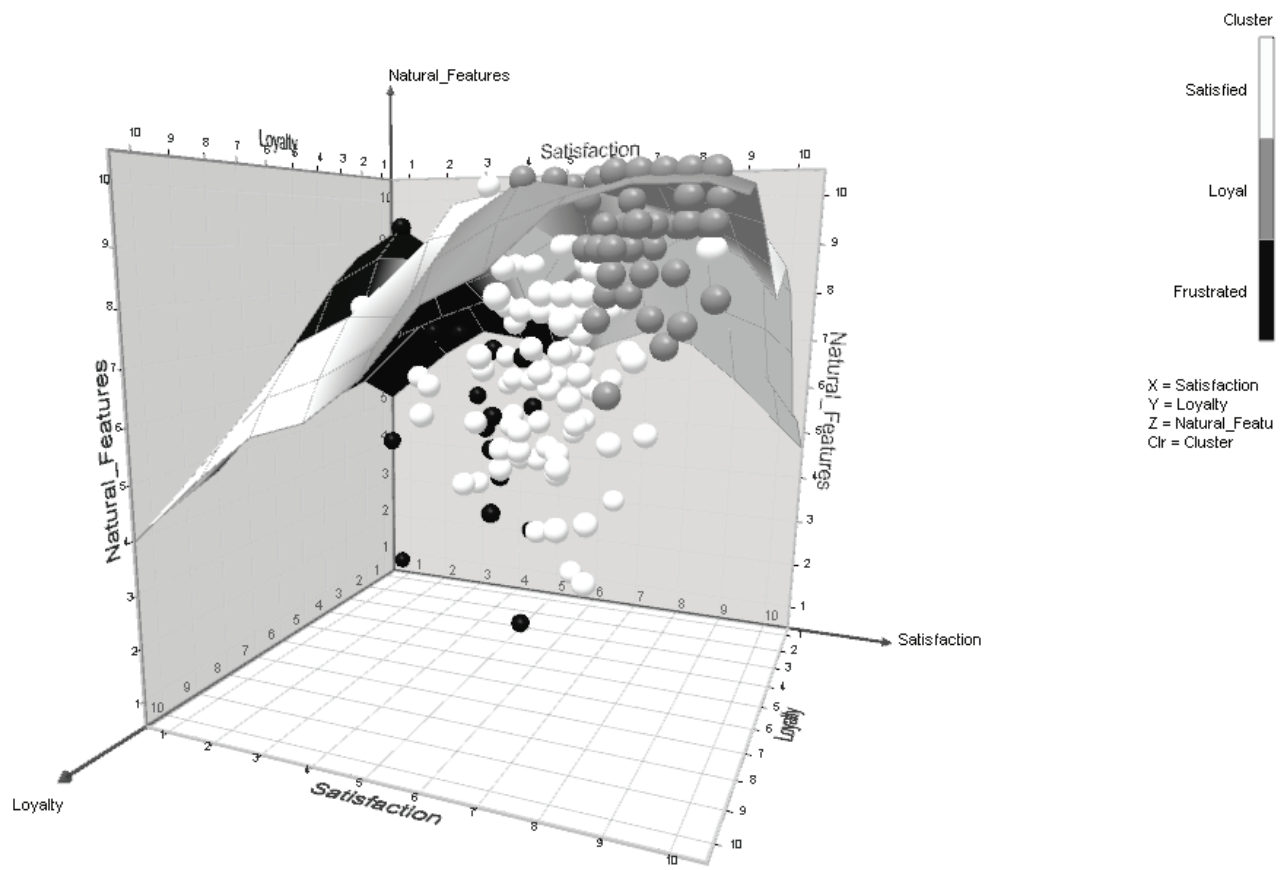

Figure 7. Natural Features, Satisfaction, and Loyalty evaluations' model

Natural Features, Satisfaction, and Loyalty evaluations' model is provided in Figure 7. It reveals that at least high level of natural features is required for the tourist to be loyal. On the other hand, there are satisfied as well as loyal tourists when the evaluation of natural features is high or very high. Consequently, 
this signifies about the specific combination among variables 'natural features', 'destination marketing', and 'environmental preservation', which distinguishes satisfied Lithuanian rural tourists from loyal. Despite this, level of natural features usually is a constant due to the requirement of very large investments from the government or businesses in order to change latter level. Consequently, because of the large costs variable 'natural features' is considered as a constant for the further analysis. Additionally, when the level of natural features remains as a constant, then such a balance of the variable 'environmental preservation' and variable 'destination marketing' should be found, that it would create a loyal tourist at the lowest costs.

In the framework of this situation, CHAID algorithm-based classification rules (which fulfilled three requirements: 1) contained together variables 'natural features', 'destination marketing', and 'environmental preservation'; 2) had hundred percent purity; 3 ) involved satisfied or loyal clusters) were distinguished (see Table 4). As a result, it is revealed that if level of natural features is low or average, then the tourist could only remain satisfied. On the other hand, if level of natural features is at the high level, then the factor, which distinguishes satisfied tourists from the loyal ones, is the level of environmental preservation. This substantiates the fact that when level of natural features is at the high level, the level of environmental preservation also must be improved to the high level in order to turn satisfied Lithuanian rural tourist into the loyal one. Moreover, if level of natural features reaches the very high level, then level of destination marketing must be enhanced to the very high level. If not, then tourists will remain satisfied instead of turning into loyal.

Table 4. The distinguished CHi-squared Automatic Interaction Detector algorithm-based Classification Rules

\begin{tabular}{|c|c|}
\hline Purity & Rules \\
\hline $100 \%$ & $\begin{array}{l}\text { If Destination Marketing in }[6 ; 6.5] \text { and Natural Features in }[9 ; 10] \text { and Environmental Preservation in } \\
{[5.5 ; 6.833] \text { then Cluster }=\text { Satisfied in } 100 \% \text { of cases }}\end{array}$ \\
\hline $100 \%$ & $\begin{array}{l}\text { If Destination Marketing in }[7 ; 8] \text { and Natural Features in }[3.333 ; 5.167] \text { and Environmental Preservation } \\
\text { in }[5.5 ; 6.833] \text { then Cluster = Satisfied in } 100 \% \text { of cases }\end{array}$ \\
\hline $100 \%$ & $\begin{array}{l}\text { If Destination Marketing in }[4.5 ; 5.5] \text { and Natural Features in }[6.5 ; 7.667] \text { and Environmental } \\
\text { Preservation in }[5.5 ; 6.833] \text { then Cluster = Satisfied in } 100 \% \text { of cases }\end{array}$ \\
\hline $100 \%$ & $\begin{array}{l}\text { If Destination Marketing in }[7.25 ; 9.5] \text { and Natural Features in }[6.5 ; 7.667] \text { and Environmental } \\
\text { Preservation in }[5.5 ; 6.833] \text { then Cluster = Satisfied in } 100 \% \text { of cases }\end{array}$ \\
\hline $100 \%$ & $\begin{array}{l}\text { If Destination Marketing in }[5.5 ; 8] \text { and Natural Features in }[7.667 ; 8.5] \text { and Environmental Preservation } \\
\text { in }[5.5 ; 6.833] \text { then Cluster = Satisfied in } 100 \% \text { of cases }\end{array}$ \\
\hline $100 \%$ & $\begin{array}{l}\text { If Natural Features in }[4.667 ; 5.167] \text { and Destination Marketing in }[3.75 ; 6.25] \text { and Environmental } \\
\text { Preservation in }[6.833 ; 7.5] \text { then Cluster = Satisfied in } 100 \% \text { of cases }\end{array}$ \\
\hline $100 \%$ & $\begin{array}{l}\text { If Natural Features in }[6.167 ; 8] \text { and Destination Marketing in }[3.75 ; 6.25] \text { and Environmental } \\
\text { Preservation in }[6.833 ; 7.5] \text { then Cluster = Satisfied in } 100 \% \text { of cases }\end{array}$ \\
\hline $100 \%$ & $\begin{array}{l}\text { If Natural Features in }[5.667 ; 6.167] \text { and Destination Marketing in }[6.25 ; 7.25] \text { and Environmental } \\
\text { Preservation in }[6.833 ; 7.5] \text { then Cluster = Satisfied in } 100 \% \text { of cases }\end{array}$ \\
\hline $100 \%$ & $\begin{array}{l}\text { If Destination Marketing in }[7 ; 7.5] \text { and Natural Features in }[9 ; 10] \text { and Environmental Preservation in } \\
{[8.167 ; 8.5] \text { then Cluster }=\text { Satisfied in } 100 \% \text { of cases }}\end{array}$ \\
\hline $100 \%$ & $\begin{array}{l}\text { If Destination Marketing in }[5.5 ; 6.25] \text { and Natural Features in }[8.5 ; 9] \text { and Environmental Preservation in } \\
{[8.167 ; 8.5] \text { then Cluster = Satisfied in } 100 \% \text { of cases }}\end{array}$ \\
\hline $100 \%$ & $\begin{array}{l}\text { If Destination Marketing in }[8 ; 8.5] \text { and Natural Features in }[6.167 ; 8.5] \text { and Environmental Preservation } \\
\text { in }[8.5 ; 8.833] \text { then Cluster = Satisfied in } 100 \% \text { of cases }\end{array}$ \\
\hline $100 \%$ & $\begin{array}{l}\text { If Natural Features in }[8 ; 9] \text { and Destination Marketing in }[3.75 ; 6.25] \text { and Environmental Preservation in } \\
{[6.833 ; 7.5] \text { then Cluster }=\text { Loyal in } 100 \% \text { of cases }}\end{array}$ \\
\hline $100 \%$ & $\begin{array}{l}\text { If Destination Marketing in }[7.5 ; 9.5] \text { and Natural Features in }[9 ; 10] \text { and Environmental Preservation in } \\
{[8.167 ; 8.5] \text { then Cluster = Loyal in } 100 \% \text { of cases }}\end{array}$ \\
\hline
\end{tabular}

Regarding the extracted variables that distinguish satisfied Lithuanian rural tourists from the loyal ones, the algorithm for turning satisfied Lithuanian rural tourist into loyal was elaborated (see Figure 8). Following the algorithm, the first step is to evaluate the level of tourist's satisfaction regarding specific rural destination by applying the LRTSI model (see Grigaliūnaite, Pileliene, 2014). If the level is low, then tourists are frustrated and attempting to turn them into loyal would not be beneficial. On the other hand, if the level of 
satisfaction is average or high, then tourists are satisfied with the specific rural destination. In this case, the level of the constant variable in the model (natural features) must be assessed.

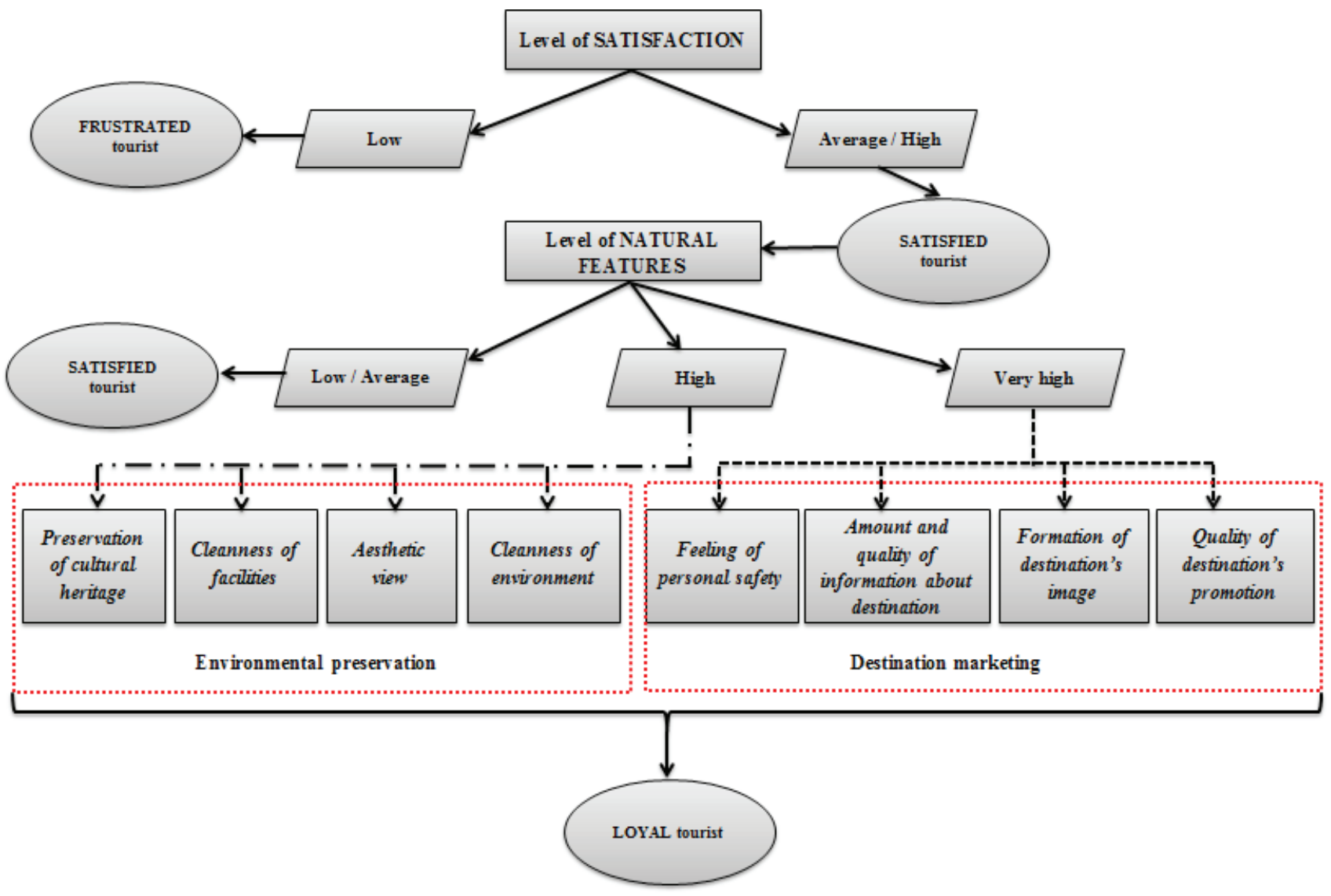

Figure 8. Algorithm for turning satisfied Lithuanian rural tourist into loyal

When level of natural features is assessed as low or average, then tourists will remain satisfied and attempting to turn them into loyal would again be non-beneficial. In contrast, if level of natural features is assessed as high, then level of environmental preservation must also reach the high level. This could be completed by the allocation of investments into the cleanness of environment, aesthetic view, cleanness of facilities, and preservation of cultural heritage.

When level of natural features is evaluated as very high, then the most important variable in order to turn satisfied tourist into the loyal becomes destination marketing, which must reach the very high level. Consequently, it could be accomplished by improving quality of destination's promotion as well as formation of destination's image. Furthermore, the amount and quality of information about destination must be enhanced and the feeling of personal safety must be guaranteed for the tourists.

All of these factors for the two latent variables were distinguished based on the outer loadings of the constructs regarding particular latent variables.

Consequently, it could be stated, that if the specific rural destination has the marvellous natural features, then strong marketing efforts become the essential factor, which attracts tourists and turns them into loyal ones. On the other hand, if specific rural destination in Lithuania does not have marvellous natural features, then there is no need for the very strong marketing efforts when seeking to turn them into loyal (average or high level is sufficient), but in this case high level of environmental preservation becomes the crucial factor that turns satisfied Lithuanian tourists into loyal.

This separation of the essential factors allows turning satisfied Lithuanian rural tourist into loyal at the lowest costs, without the investments in the whole range of factors directly affecting satisfaction and / or loyalty. 


\section{Conclusions}

Rural tourism is a valuable tool for the sustainable development of rural areas and serves as a basis for sustainable and renewable energy promotion; it makes a significant contribution to the rural economy and to the wider tourism industry. Thus, rural tourism development is an important issue for many countries, including Lithuania.

With the increasing competition among rural tourism destinations, tourist satisfaction and loyalty became very important factors for the specific rural destinations in order to profitably operate in the market. The research results revealed that at least average level of rural tourist satisfaction is essential for the possibility to turn him / her into loyal tourist. As a result, satisfied tourist might be loyal or turned from satisfied into loyal with the managerial efforts. Consequently, this substantiates the assumption that positive relationship between Lithuanian rural tourists' satisfaction and loyalty exist.

The research revealed the existence of three core segments in Lithuanian rural tourism market: satisfied, loyal, and frustrated. The frustrated cluster has no probability of becoming loyal, while satisfied cluster has a high probability of turning into the loyal cluster.

The results of the research revealed that variable 'accommodation and catering' needs to be taken under consideration when trying to make tourists satisfied, but this variable would have no effect on tourist loyalty. Furthermore, variable 'activities in destination' might be taken under consideration when creating destination marketing, but activities in destination also would not make tourists loyal. Moreover, variable 'destination aesthetics' has insufficient effect on satisfaction as well as loyalty that it could influence the process of turning satisfied Lithuanian rural tourist into the loyal one.

Subsequently, variables that have to be considered to turn already satisfied tourists into loyal are: 'natural features', 'destination marketing' and 'environmental preservation'. Considering that the variable 'natural features' remains at the constant level due to the requirement of large investments, 'environmental preservation' and 'destination marketing' are variables necessitating specific level of compatibility.

Consequently, the specific rural destination, which has the spectacular natural features, needs strong marketing efforts to turn satisfied Lithuanian rural tourists into loyal ones. On the other hand, for the specific rural destination in Lithuania, which does not have spectacular natural features, high level of environmental preservation becomes the crucial factor that helps turning satisfied Lithuanian tourists into loyal.

This separation of the essential factors allows turning satisfied Lithuanian tourist into loyal at the lowest costs, without the investments in the whole range of factors directly affecting satisfaction and / or loyalty.

\section{References}

Alegre, J., Garau, J. (2010). Tourist Satisfaction and Dissatisfaction. Annals of Tourism Research, Vol. 37, No. 1, p. 52-73. Available at: http://www.sciencedirect.com/science/article/pii/S0160738309000929 [2014-07-09].

Baležentis, T., Kriščiukaitienė, I., Baležentis, A., Garland, R. (2012). Rural tourism development in Lithuania (20032010) - A quantitative analysis. Tourism Management Perspectives, Vol. 2, No. 3, p. 1-6.

Ghanian, M., Ghoochani, O. M., Crotts, J. C. (2014). An application of European Performance Satisfaction Index towards rural tourism: The case of western Iran. Tourism Management Perspectives, Vol. 11, p. 77-82.

Grigaliūnaite, V., Pilelienė, L. (2014). Rural Tourist Satisfaction Index: A Case of Lithuania. Materials of 20th Annual International Scientific Conference "Research for Rural Development 2014". Jelgava (Forthcoming).

Haven-Tang, C., Jones, I. (2012). Local leadership for rural tourism development: A case study of Adventa, Monmouthshire, UK. Tourism Management Perspectives, No. 4, p. 28-35.

Jurdana, D., Frleta, D. (2012). Tourism Development of Rural Areas - the Customer Perspective. Conference Proceedings: International Conference of the Faculty of Economics Sarajevo (ICES), p. 191-205.

Khalil, F. I., Sambotin, L., Mayer, M., Jitaru, D., Tirchi, R. (2012). Study on the influence of rural tourism on the environment. Agricultural Management, Vol. 14, No. 4, p. 261-264.

Lo, M., Songan, P., Mohamad, A., Yeo, A. W. (2011). Rural Destinations and tourists' Satisfaction. Journal of Services Research, Vol. 11, No. 2, p. 59-74.

Marcu, V., Dumitrescu, C., Iosim, I., Marin, D., Dincu, A. M., Moisa, S. (2013). Tourism contribution to economy development. Agricultural Management, Vol. 15, No. 4, p. 241-246. 
Peña, A., Jamilena, D., Molina, M. (2012). The perceived value of the rural tourism stay and its effect on rural tourist behavior. Journal of Sustainable Tourism, Vol. 20, No. 8, p. 1045-1065.

Peña, A., Jamilena, D., Molina, M. (2013). Antecedents of loyalty toward rural hospitality enterprises: The moderating effect of the customer's previous experience. International Journal of Hospitality Management, Vol. 34, p. 127-137.

Phillips, W. J., Wolfe, K., Hodur, N., Leistritz, F. L. (2013). Tourist Word of Mouth and Revisit Intentions to Rural Tourism Destinations: a Case of North Dakota, USA. International Journal of Tourism Research, Vol. 15, p. 93-104.

Pilelienè, L., Grigaliūnaite, V. (2014). Lietuvos turistų pasitenkinimo indekso modelis: teorinès įžvalgos. Organizaciju vadyba: Sisteminiai tyrimai, Nr. 69, p. 107-118.

Pop, I., Ghereş, M. (2013). Tourist satisfaction in rural areas - a comparative study on rural areas from Romania and Hungary. Proceedings of The International Conference Marketing - from Information to Decision, p. 6223-6235.

Radac, B. A., Ciolac, R., Iosim, I., Merce, I. I., Dincu, A. M., Matias, C. G. (2013). The importance of effective communication in rural tourism. Agricultural Management, Vol. 15, No. 4, p. 267-270.

Radaca, A. B., Csosz, I., Merce, I. I., Iosim, I., Dincu, A. M., Martin, S. C. (2012). Modalities to promote Romanian rural tourism. Agricultural Management, Vol. 14, No. 4, p. 363-368.

Randelli, F., Romei, P., Tortora, M. (2014). An evolutionary approach to the study of rural tourism: The case of Tuscany. Land Use Policy, Vol. 38, p. 276-281.

Rid, W., Ezeuduji, I. O., Pröbstl-Haider, U. (2014). Segmentation by motivation for rural tourism activities in The Gambia. Tourism Management, No. 40, p. 102-116.

Shirazi, F., Mat Som, A. (2013). Relationship Marketing and Destination Loyalty: Evidence from Penang, Malaysia. International Journal of Management \& Marketing Research (IJMMR), Vol. 6, No. 1, p. 95-106.

Sun, X., Chi, C. G. Q., Xu, H. (2013). Developing destination loyalty: the case of Hainan Island. Annals of Tourism Research, Vol. 43, p. 547-577.

\title{
LIETUVOS KAIMO TURISTU PASITENKINIMAS IR LOJALUMAS: SEGMENTAVIMAS IR VADYBINIAI SPRENDIMAI
}

\author{
Viktorija Grigaliūnaitė, Lina Pilelienè \\ Vytauto Didžiojo universitetas (Lietuva) \\ Santrauka
}

Lietuvoje, kaip ir daugelyje kitu greitai besivystančių šalių, turizmas tampa labai svarbia ir greitai augančia industrija. Kaimo turizmas - tai kaimiškujų vietovių darnios plètros priemonė (Peña ir kt., 2012), leidžianti skatinti darnų atsinaujinančios energijos vartojimą (Baležentis ir kt., 2012). Kita vertus, kaimo turizmas daro didelę įtaką kaimo ekonomikai ir bendrajai turizmo plètrai (Haven-Tang, Jones, 2012). Straipsnyje sprendžiama problema keliama klausimu, kokie veiksniai lemia Lietuvos kaimo turistų lojalumą ir kaip padaryti, kad patenkinti turistai taptų lojaliais turistais? Straipsnio objektas - Lietuvos kaimo turistų lojalumą lemiantys veiksniai. Straipsnio tikslas - nustatyti pagrindinius veiksnius, kurie lemia Lietuvos kaimo turistų lojalumą. Tyrimo metodai: siekiant straipsnio tikslo, atlikta mokslinès literatūros analizė ir sintezè. Turistų nuostatos ir vertinimai dèl Lietuvos kaimo turistinių vietovių nustatyti anketinès apklausos metodu. Atliekant statistinę duomenų analizę, taikyti struktūrinio lygčių modeliavimo, pasitelkiant mažiausius dalinius kvadratus, regresijos ir klasifikavimo medžio metodai. Sudarant Lietuvos kaimo turisto prototipą ir nustatant Lietuvos kaimo turizmo rinkos struktūrą, taikyta klasterinè analizè.

Empirinio tyrimo rezultatai atskleidè, kad siekiant turisto lojalumo, būtinas bent vidutinis pasitenkinimo turistine kaimo vietove lygis. Esant minėtam pasitenkinimo lygiui, taikant tinkamas vadybines priemones, galima paskatinti turisto lojalumą. Tyrimo rezultatai pagrindè prielaidą, kad egzistuoja teigiamas ryšys tarp Lietuvos kaimo turistų pasitenkinimo ir lojalumo. Tyrimo rezultatai atskleidè, kad kintamasis ,apgyvendinimas ir maitinimas" yra svarbūs, siekiant, kad turistas liktų patenkintas, tačiau turisto lojalumui šis kintamasis įtakos neturi. Tyrimu nustatyta, kad Lietuvos turistinei kaimo vietovei, kurioje ịspūdinga gamtinè aplinka 
(t. y. kintamasis „gamtinè aplinka“ vertinamas labai gerai), būtina taikyti rinkodaros priemones, siekiant, kad šia vietove patenkinti turistai taptų lojalūs. Kita vertus, jei Lietuvos turistinèje kaimo vietovèje gamtinè aplinka vertinama tik gerai, būtina palaikyti labai aukštą ,vietovès autentiškumo“ lygị ir šis veiksnys tampa lemiamu, siekiant patenkintą turistą paversti lojaliu. Tyrimu nustatyta, kad nesant aukšto arba labai aukšto gamtinès aplinkos vertinimo jokie vadybiniai sprendimai negali paskatinti turistų lojalumo, net jei jie bus patenkinti.

PAGRINDINIAI ŽODŽIAI: kaimo turizmas, Lietuvos turizmas, turistu lojalumas, turistu pasitenkinimas.

JEL KLASIFIKACIJA: M310, M390. 